\title{
Strategic priorities in the industrial poultry products competitiveness management system
}

\author{
Aleksey Panov ${ }^{1, *}$, Natalya Panova $^{1}$, Galina Zvereva ${ }^{1}$, Tatjana Daeva ${ }^{1}$, Andrey Mozgovoy ${ }^{2}$, \\ Alexey Beskopilniy ${ }^{2}$ \\ ${ }^{1}$ Volgograd State Agrarian University, Volgograd, 26, Universitetskiy Prospect \\ ${ }^{2}$ Don State Technical University, Gagarin sq., 1, 344000, Rostov-on-Don, Russia
}

\begin{abstract}
Worldwide globalization and the development of market relations in Russia is accompanied by toughening the competition between foreign and Russian producers. In these conditions, enterprise managers are forced to look for new ways to increase their products competitiveness, taking into account the changing market situation. As practice shows, in modern business conditions, only those solutions that are based on a deep understanding of the competitive market struggle nature and mechanisms are effective. The stability of the meat market is determined by the stability of the market entities activities. This stability is achieved by combining the effective implementation of their competitive strategy with the scientifically sound economic and social policies of the state, aimed at ensuring favorable conditions for the economic entities functioning and improving the population living standards.
\end{abstract}

\section{Introduction}

The meat processing enterprise market stability depends on its products competitiveness. The enterprise competitiveness is determined by its own and borrowed resources use efficiency. A prerequisite for the enterprise success is the goods production and sale that can withstand market competition.

The competitiveness of poultry meat products means the degree of its attractiveness for a potential buyer in comparison with similar products on the market, and is determined by such advantages as quality, price of products and image of the manufacturer.

An enterprise is competitive if its potential is realized, which allows it to form a sustainable market advantage [1]. The enterprise successful functioning in a competitive environment provides an increase in its market stability, and the long-term (at least one year) preservation of its activity maximum efficiency indicates its potential successful realization. But the state of the environment and the market should be considered favorable only if no enterprise makes it difficult for other business entities to access the market, i.e. does not limit the development of competition. 
Modern economic processes in all areas of agricultural production occur in a competitive environment. It largely determines the activity of the poultry-food sub-complex entities for the products production and sale.

Despite the fact that under the state territorial division there is no competition among the regions, since separate territorial zones are an equal part of an integral state space, their food activities proceed in different ways.

\section{Materials and methods}

The research was carried out by using data on poultry enterprises in Russia and the Volgograd region, with varying degrees of readiness for activities in a competitive environment. The dialectical method, which has a general scientific character; playing a crucial role in economic cognition logical methods of economic research; qualitative method of economic analysis were used as research methods.

\section{Results}

According to the existing classification, the regions of the Russian Federation are subdivided into food producing and consuming it [2]. The productive function of the region is due, primarily, to the fact that there are more favorable conditions within it for the formation of competitive advantages in the production of a product particular type. Therefore, the implementation of this function in the region may indicate competitiveness, both of certain types of products, and of the territorial entity as a whole.

The Southern Federal District, which also includes the Volgograd Region, objectively, based on zonal conditions, is a producing one. In this regard, it should be characterized by an export policy in relation to the main types of agricultural products, including poultry.

Market laws indicate that it is advisable to increase production to the extent determined by demand, otherwise overproduction may lead to its lack of demand from potential buyers. However, taking into account the production function of the regions included in the Southern Federal District, it should be concluded that the demand limitation within the Volgograd region does not work in this case and equilibrium can be achieved constantly with an increasing supply of products due to their export. However, over the past twenty years, there has been poultry meat products import into the region [3].

In a competitive market, counter flows of products are inevitable, especially within the producing region, primarily between the regions and territories included in it.

The current situation is determined by many factors: firstly, the change in the population of the region; secondly, a change in its purchasing power; thirdly, the competitiveness of products. The first two factors have not changed significantly in recent years, and the latter deserves special attention.

Table 1 - Main characteristics of the industrial enterprises strategic cost management (SCM) based on the marketing concept

\begin{tabular}{|l|l|l|}
\hline $\begin{array}{c}\text { Conditions for effective } \\
\text { SCM }\end{array}$ & $\begin{array}{c}\text { Benefits from the } \\
\text { SCM implementation }\end{array}$ & $\begin{array}{l}\text { Possible adverse factors and consequences } \\
\text { affecting SCM effectiveness }\end{array}$ \\
\hline $\begin{array}{l}\text { 1. There is access to } \\
\text { sources of cheap raw } \\
\text { materials, labor, or } \\
\text { other sources of }\end{array}$ & $\begin{array}{l}\text { arises to use low costs } \\
\text { in the struggle for } \\
\text { market share, to }\end{array}$ & $\begin{array}{l}\text { 1. Inflationary cost increases, undermining } \\
\text { the organization's ability to reduce } \\
\text { production costs. }\end{array}$ \\
$\begin{array}{l}\text { production Change in consumer preferences, their } \\
\text { reducing. }\end{array}$ cost & $\begin{array}{l}\text { provide protection } \\
\text { from a price war, or, }\end{array}$ & $\begin{array}{l}\text { sensitivity to prices in favor of the goods, } \\
\text { services quality and other characteristics. }\end{array}$ \\
2. The market is & conversely, to conduct & 3. The appearance of technological \\
\hline
\end{tabular}




\begin{tabular}{|c|c|c|}
\hline $\begin{array}{l}\text { dominated by price } \\
\text { competition. } \\
\text { 3. Trademark } \\
\text { differences are of little } \\
\text { significance to buyers. } \\
\text { 4. Demand for products } \\
\text { is highly elastic in price } \\
\text { and fairly uniform. } \\
\text { 5. Industry products are } \\
\text { standardized, the buyer } \\
\text { can purchase it from } \\
\text { different sellers. }\end{array}$ & $\begin{array}{l}\text { an offensive pricing } \\
\text { policy. } \\
\text { 2. The organization's } \\
\text { ability to dictate prices } \\
\text { acts as an additional } \\
\text { barrier to entry in the } \\
\text { industry. } \\
\text { 3. Similarly, there is a } \\
\text { barrier to the } \\
\text { emergence } \\
\text { substitute products. }\end{array}$ & $\begin{array}{l}\text { innovations that negate the cost advantages. } \\
\text { 4. Inability to grasp the need to change } \\
\text { products or market segments as the result of } \\
\text { excessive enthusiasm for the problem of } \\
\text { cost reduction. } \\
\text { 5. Passion for one product production, } \\
\text { forgetting about the need to update products. } \\
\text { Typical mistakes of domestic leaders } \\
\text { when using information about costs in } \\
\text { strategic management: } \\
\text { 1. Orientation of the cost management } \\
\text { system to information on direct costs. } \\
\text { 2. Lack of attention to supply problems. } \\
3 \text {. Inability to recognize and use the } \\
\text { relationships between business functions. } \\
\text { 4. Cost management without changing the } \\
\text { existing structure of business processes. } \\
5 \text {. Incorrect diagnostics of various cost } \\
\text { behavior factors and their dynamics } \\
\text { patterns: including the lack of understanding } \\
\text { what factors underlie cost advantages, which } \\
\text { can lead to a deterioration in the company } \\
\text { competitive position; enterprises often try to } \\
\text { reduce costs in conflicting ways; an } \\
\text { economic entity can unwittingly subsidize } \\
\text { one business function at the expense of } \\
\text { another, without distinguishing segments in } \\
\text { which costs behave differently. } \\
6 \text {. Excessive passion for minimizing costs in } \\
\text { the context of the differentiation strategy } \\
\text { implementation. }\end{array}$ \\
\hline
\end{tabular}

Competitiveness should be defined as a property of a product, characterized by the specific need real and potential satisfaction degree in comparison with similar objects presented on this market. It determines the ability to withstand competition in comparison with similar objects in this market [4].

The increase in the product competitiveness is indicated by its penetration into new markets and their conquest. As you know, poultry is one of the most highly efficient and precocious industries. The poultry meat slaughter yield on average is $66 \%$ of live weight, which is 1.5 times higher than that in cattle. In this regard, poultry farming is most susceptible to endogenous and exogenous factors that determine competitive advantages; the presence of the latter can be judged by various characteristics: quality, price, production costs.

Each of these competitive advantages needs constant strengthening, which can be facilitated by the implementation of strategic marketing management (Figure 1).

The product priority indicator of competitiveness remains the quality. The absence of a professional marketing service in most poultry farms results in a loss of a certain share of the benefits.

The processes of global integration, despite the sanctions and embargoes, significantly affect the poultry products domestic producers' economic interests. Russia's entry into the WTO in 2012 was to create more favorable conditions for access to world markets, attracting foreign investment and technologies to Russia. At the same time, the process of opening one's own market should have been accompanied by harmonization of the 
domestic legal and economic space with the world. However, 2014 brought its own corrections, such factors as the war of sanctions with the West, falling oil prices and the devaluation of the ruble came to the fore.

Despite this, Russian enterprises need to be worthy in the competition in both domestic and foreign (primarily Chinese) markets. It is necessary to identify promising directions for the strategic behavior of domestic producers that would help to ensure that they have advantages or equal opportunities in the world market.

Poultry farms in the Volgograd region need to engage actively in the process of reforming the certification system and introducing product safety control systems on farms [5]. At the international level, the concept of HACCP (Hazard analysis and critical control points) was recognized and most widely used.

Today, domestic food enterprises seeking to enter foreign markets often face the requirement to use a system of risk analysis and critical control points (HACCP), since the principles and mechanisms laid down in it significantly reduce the possibility of the products consumers' life and health endangering [6]. In the Volgograd region, one poultry factory does not have a certificate of compliance with the international standard ISO 9001, which indicates the impossibility of their entry into foreign markets. It should be noted that poultry enterprises in the region supply their products to other subjects of the Russian Federation; however, they occupy only $30 \%$ in the food market of the Volgograd region. The main poultry meat suppliers are: a group of agricultural enterprises "Cherkizovo", "Prioskolje", "Miratorg" and others.

Today we can talk about the increased competition in the domestic market not from the side of imports, but from the products of Russia's other regions, which exacerbates a number of problems inherent in the poultry farms of the Volgograd region:

- traditional focus on cost-saving strategies;

- strong dependence of the final products pricing on the commodity markets state in connection with the products material consumption;

- difficulties in implementing the product differentiation strategy in connection with technical and economic difficulties.

Let us evaluate the strategic positions of regional poultry production enterprises in order to determine their optimal strategy for market behavior in the current situation.

The traditional Russian strategy of cost saving, associated with the short-term effect of maximizing profits, sometimes leads to a loss in the quality of products. Orientation to the long term and financial potential will allow leaders of the trailer product market to successfully engage in price competition.

The need for Volgograd producers to abandon the strategy of low costs and prices is obvious, which is confirmed, in particular, by their dependence on the unstable state of the feed market [7].

The lack of benefits for this strategy requires its replacement. An alternative is differentiation and focusing strategies. The first difficulty in their implementation will be a rather tight binding of food products to a single system of all-Union State Standard and Technical Specifications (almost identical products are produced at various enterprises). Therefore, the main trump card of differentiation in food production is the trademarks management of and the regulation of the product quality level. The transition to a differentiation strategy for local poultry enterprises will be complicated by the lack of financial investments in marketing, branding, quality systems, as well as the information base and communication systems development low level.

Of all the potential reserves for increasing competitiveness, the benefits of integrated production can be singled out.

In the poultry industry, the most common varieties of integrated structures are unions and associations, agro-industrial and financial-industrial groups, companies that own the 
land of their enterprises, holdings created by centralizing certain functions and uniting the property of participants, agricultural companies.

The experience of foreign and advanced poultry farms in Russia indicates that the poultry farming effectiveness is possible only in cooperation with grain producers, feed mills, processing plants, and trade organizations.

The term "vertical integration" is used in agriculture primarily to determine contractual relations between agricultural enterprises and enterprises - buyers or suppliers from other sectors of the economy. Here we are mainly talking about vertical cooperation or coordination, in the framework of which its individual parts are preserved, if not complete, then at least formal independence. Vertical integration eliminates unnecessary links, reduces the funds and time loss during the transition from one technological stage to another, and creates opportunities for better use of existing facilities, profit.

The systems transition into associations with cost-effective inter-farm relations and other forms of cooperation and integration will help to solve the problems that have arisen for the industry as a whole.

Improving the integration efficiency is to achieve the most complete and rational use of agricultural machinery and equipment, material and financial resources, saving working time, raw materials, fuel and energy.

The economic effect is achieved by increasing its scale, deepening the enterprises specialization, improving the products quality and competitiveness, reducing costs, including the products sale, identifying priority areas for investment, introducing the achievements of scientific and technological progress in all sectors, solving social issues and, first of all, increase motivation for work, each employee material support in accordance with his labor, property and monetary contribution.

There is every reason to believe that technological innovations in industrial poultry farming, as well as intersectoral integration will allow enterprises to expand their sphere of influence in other regions and increase the investment attractiveness of the region as a whole.

The priority of poultry farming with the agricultural sector state support, which has already proved its competitive advantages, compared, for example, with the production of cattle meat, should be the rule [8]. The next important direction of agricultural policy in the field of poultry farming should be the elimination of "trade wars" between regions that are particularly acute in poultry farming; it is necessary to establish regulations for supporting the agricultural sector at the regional level, which would exclude the possibility of dumping one region in the market of another region.

Thus, the carried out research overall conclusion is that today the poultry production development in the Volgograd region is least dependent on imports, so the support policy should be reviewed both in terms of foreign trade regulation and in terms of domestic policy.

Improving the competitiveness of local poultry products directly depends on the possibility of introducing modern technologies for poultry farming based on the use of highly effective and high-quality compound feeds, which occupy the largest share in the cost of poultry meat production.

It also necessary: to create a feed grain regional reserve (the Volgograd region is among the five regions, the largest grain producers); adjust feed prices; reduce the value added tax of animal feed components imported into the region that are either not produced in Russia or are produced in insufficient quantities and with unsatisfactory quality; to establish benefits on tariffs for the poultry meat, animal feed and their components railway transportation.

In the Volgograd region, industry updates can occur in the following areas. First of all, this is the maximum use of the existing technological potential with the simultaneous 
investment in the products new types' development with improved consumer properties, which means that they are in high demand [9]. It is also necessary to expand the progressive production base due to the resource-saving technologies already developed and partially introduced at the region poultry farms, which do not require large capital investments.

Practical components of evaluating the sectoral enterprise marketing activities

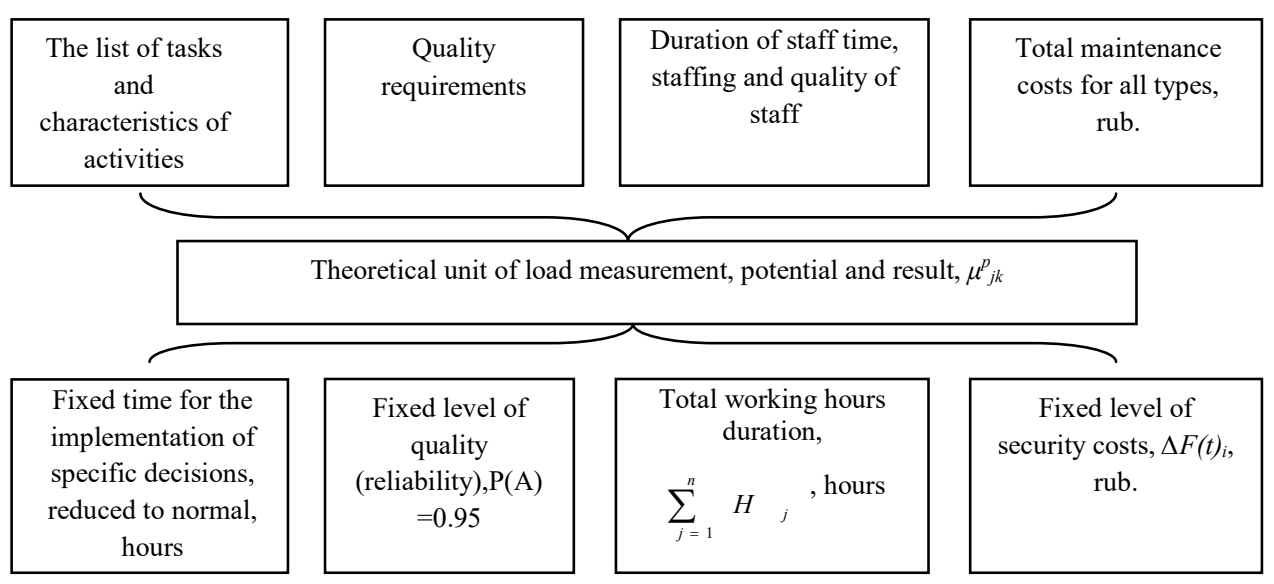

Theoretical components of marketing performance assessment

Figure 1 The structure of the marketing management potential and the result measurement comprehensive unit formation

Despite the high appreciation of poultry products in the region, in our opinion, producers have significant reserves to increase their competitiveness. It is only necessary to use the organizational and economic mechanism, the competitive strategy formation should be considered as its main lever [10]. The main strategic goal of such poultry organizations should be to defend their position in the poultry meat market and its processed products through the development of a distribution network, image development, and a personal brand.

In addition, it is advisable to carry out constant monitor of the implemented marketing policy and evaluate its effectiveness (Figure 2).

This will allow to manage the final products quality and assortment in accordance with market requirements quickly and efficiently and carry out created associations' systematic development, taking into account the whole complex of factors involved in this process. The application of this approach will allow industrial poultry enterprises to solve a very urgent problem of high-quality poultry products producing, which will allow them to enter the world market successfully.

\section{References.}

1. K.V. Korsakov, A.A. Vasiliev, L.A. Sivokhina, M.V. Zabelina, R.N. Murtazaeva. T.V. Daeva, V.A. Kokorev, Advances in Animal and Veterinary Sciences, 7, 66-70 (2019)

2. A. Ovchinnikov, Z. Kozenko, M. Bichkov, V. Kabanov, A. Karpova, European Research Studies Journal, 3, 307-315 (2015)

3. A.S. Ovchinnikov, N.V. Ivanova, N.N. Balashova, Espacios, 36, 14 (2018)

4. T.N. Litvinova, Advances in Intelligent Systems and Computing, 622, 284-290 (2018)

5. L.V. Popova, D.A. Korobeynikov, O.M. Korobeynikova, A.A. Panov, Journal of Applied 
Economic Sciences, 6, 1034-1044 (2016)

6. A. Nawab, F. Ibtisham, G. Li, B. Kieser, L. An, Journal of Thermal Biology, 78, 131139 (2018)

7. L.V Popova, T.A. Dugina, N.S. Panova, A.G. Dosova, N.N. Skiter, Advances in Intelligent Systems and Computing, 622, 681-687 (2018)

8. R.N. Murtazayeva, G.N. Zvereva, D.A. Grebneva, The state of feed production of the Volgograd region and the range of areas for poultry feeding. Proc. of the Lower Volga Agro-University Comp, 3(55), 235-244 (2019)

9. E.G. Popkova, Y.G. Tyurina, A.A. Sozinova, L.V. Bychkova, O.M. Zemskova, M.F. Serebryakova, N.V. Lazareva, Contributions to Economics, 9783319454610, 55-63 (2017)

10. F. S. Foltean, Journal of Business Research, 104, 520-528 (2019) 